[Agr. Biol. Chem., Vol. 30, No. 7, p. 674 682, 1966]

\title{
Biochemical Effects of Fatty Acid and its Derivatives \\ on L-Glutamic Acid Fermentation
}

\author{
Part IV Biotin Content of Growing Cells of \\ Brevibacterium lactofermentum ${ }^{\dagger}$
}

\author{
By Koichi Takinami, Yasutsugu Yamada and Hiroshi Okada \\ Central Research Laboratories of Ajinomoto Co., Inc., Kawasaki \\ Received January 27, 1966
}

\begin{abstract}
Brev. lactofermentum rapidly took up biotin from culture medium and stored it in the cells. The saturation level of the stored biotin $\left(3.8 \times 10^{4}\right.$ molecules/cell $)$ exceeded the level required for the maximum growth by ten times, and the minimum level $\left(1.3 \times 10^{3}\right.$ molecules/cell) was the most adequate to the accumulation of L-glutamic acid. The stored cellular biotin over the minimum level was metabolically available in the subsequent culture lacking in supplemented biotin. The cellular biotin was gradually reduced to the minimum level with the multiplication of the cells, and them the accumulation of Lglutamic acid was observed. This relation between the level of cellular biotin and the accumulation of L-glutamic acid was impaired by the addition of Tween 60 or some saturated fatty acid. In the presence of biotin and Tween 60 the biotin-saturated cells turned into cells capable of accumulating L-glutamic acid keeping the maximum level; and in the same medium the cells having the minimum amount of biotin took up biotin and then were saturated with it, and yet the cells preserved the acid-accumulating property. It was confirmed with the use of bioautographic technique and avidin test that the biotin released from the cells by acid hydrolysis was identical with authentic $d$-biotin.
\end{abstract}

\section{INTRODUCTION}

Since it was found that the suboptimal level of biotin in fermentation medium was essential for the accumulation of L-glutamic acid, ${ }^{1)}$ several groups of workers have studied on the actions of the menstruum biotin. Most recently the problem was still investigated as the considerable subject of L-glutamic acid fermentation. $^{2 \sim 5)}$ In these investigations, however, the effects of biotin were considered to be related

$\dagger$ This investigation was presented at the Annual Meeting of the Agricultural Chemical Society of Japan in April, 1965, in Tokyo.

1) K. Tanaka, T. Iwasaki and S. Kinoshita. J. Agr. Chem. Soc. Japan,34, 593 (1960).

2) K. Oishi and K. Aida, This Journal 29, 83 (1965).

3) K. Kono, Y. Iijima, T. Oki, N. Miyachi and A. Ozaki, Amino Acid and Nucleic Acid, 11, 99 (1965).

4) K. Tanaka, K. Oshima, K. Kimura and S. Kinoshita, ibid., 11, 106 (1965)

5) S. Otsuka, R. Miyajima and I. Shiio, ibid., 12, 16 (1965). merely to its concentration in culture medium, and little is known of the uptake of biotin into the microbial cells ${ }^{6}$ and of its amounts, form and localization in the cells. Already there have been several investigations on the uptake of some kinds of vitamin by microorganisms other than L-glutamic acid-producing bacteria; biotin by Lactabacillus arabinosus, ${ }^{71}$ vitamin $\mathrm{B}_{12}$ by Escherichia coli, ${ }^{\mathbf{8})}$ Lactobacillus leichmannii ${ }^{9)}$ and $L$. delbrueckii, ${ }^{10)}$ and folic acid by Streptococcus faecalis. ${ }^{11}$ The results de-

6) K. Oishi, K. Aida and T. Uemura, Annual Meeting of Agr. Chem. Soc. of Japan in July, 1964, in Sapporo. 7) H.C. Lichstein and J.R. Waller, $J$. Bacteriol., 81, 65 (1961).

8) E. L. Oginsky, Arch. Biochem. Biophys., 36, 71 (1952). 9) S. Kashket, J. T. Kaufman and W. S. Beck, Biochim. Biophys. Acta, 64, 441 (1962).

10) K. Kitahara and T. Sasaki, J. Gen. Appl. Microbiol., $9,213(1963)$

11) R. C. Wood and G. H. Hitchings, J. Biol. Chem., 234, 
scribed in those reports ${ }^{6-11}$ were obtained exclusively with non-proliferating cells, and growing cells were scarcely employed in the studies on the uptake of the vitamins.

On the other hand, it has been reported that hydrophilic fatty acid eaters, which had a remarkable effect on the accumulation of $\mathrm{L}$-glutamic acid in the presence of sufficient amounts of biotin, were incapable of having the effect on non-proliferating cells. ${ }^{12,13)}$ On that account, the use of growing cells seems desirable for the studies on the relation between biotin and fatty acid. In the present investigation, particular experiments were made not only on the uptake of biotin by growing cells but on the change of biotin content in cells during the subsequent growth. Consequently a close relation was found between the biotin level of the cells and the accumulation of $\mathrm{L}$-glutamic acid. In addition, the effects of fatty acid and its ester, such as Tween 60 and stearic acid, were investigated concerning the above relation.

\section{EXPERIMENTAL}

\section{Inoculum and Culture}

Test microorganism and culture techniques were the same as those described previously.14) Brevibacterium lactofermentum No. 2256 grown on nutrient agar was cultured in the following medium at $31.5^{\circ} \mathrm{C}$. One liter of basal medium contained glucose, $36 \mathrm{~g}$; urea, $2 \mathrm{~g} ; \mathrm{KH}_{2} \mathrm{PO}_{4}, 1 \mathrm{~g} ; \mathrm{MgSO}_{4} \cdot 7 \mathrm{H}_{2} \mathrm{O}, 0.4 \mathrm{~g} ; \mathrm{FeSO}_{4} \cdot 7 \mathrm{H}_{2} \mathrm{O}$, $10 \mathrm{mg} ; \mathrm{MnSO}_{4} \cdot 4 \mathrm{H}_{2} \mathrm{O}, 8.1 \mathrm{mg}$ and Aji-eki (hydrolysate of soybean protein), $5 \mathrm{ml}$. Desired amounts of biotin were supplemented to the basal medium.

\section{Subsequent Culture}

The fully grown cells obtained in the culture described above were harvested by centrifugation and washed with 0.2 per cent aqueous solution of potassium chloride. Then the cells were inoculated in $30 \mathrm{ml}$ of fresh medium which was composed of the basal medium and the desired amounts of biotin and

12) I. Shiio, S. Otsuka and N. Katsuya, J. Biochem., 53, 333 (1963).

13) K. Takinami, H. Okada and T. Tsunoda, This Journal, 27, 858 (1963).

14) K. Takinami, H. Yoshii, H. Tsuri and H. Okada, This Journal, 29, 351 (1965).
Tween 60. The subsequent culture was carried out at $31.5^{\circ} \mathrm{C}$ on a reciprocal shaker and continued until glucose was consumed. During the culture sterile urea solution (approximately 45\%) was added to maintain the $\mathrm{pH}$ of the culture medium between 7 and 8 .

\section{Biotin Assay}

Bacterial cells were harvested by immediate centrifugation at $2^{\circ} \mathrm{C}$, followed by twice rapid washes with water. Throughout the washes the cellular biotin was thoroughly retained within the cells, for no biotin was determined in the washings. According to the method employed by many investigators, ${ }^{15 \sim 18}$ ) the washed cells were resuspended in $6 \mathrm{~N}$ sulfuric acid and heated at $120^{\circ} \mathrm{C}$ for 90 minutes to liberate cellular biotin in free form. After cooled to room temperature, the hydrolysate was neutralized with potassium hydroxide solution and adjusted to $\mathrm{pH} 6.8$. The hydrolysates and the supernatants of the culture broth were then assayed microbiologically with the use of Lactobacillus arabinosus 17-5. For the determination of biotin with $L$. arabinosus was employed a modified medium of pantothenic acid assay, ${ }^{19}$ ) excluding biotin and supplementing pantothenic acid.

\section{Chromatography}

Dry cells of Brev. lactofermentum were hydrolyzed as described above. The hydrolysate was neutralized with barium hydroxide solution and the mixture was filtered to remove the insoluble salts. The residues were washed three times with water and washings were combined with the filtrate. Aliquot of the clear solution and authentic $d$-biotin were applied qualitatively to sheets of Toyoroshi No. 51 filter paper. According to descending technique, each paper was developed at room temperature in a solvent system: $n$-butanol-water-acetic acid, $4: 5: 1.20,21)$ After the solvent front had moved $25 \mathrm{~cm}$, the paper was removed from the solvent and air-dried. The paper strip was cut into ten sections, which were eluted in tubes with $10 \mathrm{ml}$ of deionized water at $110^{\circ} \mathrm{C}$ for 2 minutes. Bioautographic technique was used for the

15) L.D. Wright and H.R. Skeggs, Proc. Soc. Exp. Biol. Med., 56, 95 (1944).

16) J.P. Bowden and W. H. Peterson, J. Biol. Chem., 178, 533 (1949).

17) R. B. Ferguson. H.C. Lichstein and D. Glick, Arch. Biochem. Biophys., 89, 31 (1960).

18) C. K. Pai and H.C. Lichstein, Biochim. Biophys. Acta, 100, 28 (1965).

19) U.S. Pharmacopeia, XVI, 871 (1960).

20) L. D. Wright, E. L. Cresson and C. A. Driscoll, Proc. Soc. Exp. Biol. Med., 86, 480 (1954).

21) M. Waite and S. J. Wakil, J. Biol. Chem., 238, 81 (1963). 
detection of the biotin with $L$, arabinosus as a test organism. Acidity was plotted as a function of the distance from the origin.

Determination of Bacterial Growth, Glucose and L-Glutamic Acid

The growth of Brev. lactofermentum was conveniently indicated by the absorbance of cell suspension at $\left.562 \mathrm{~m} \mu .{ }^{14}\right)$ In order to obtain more precise result, the cells were harvested by centrifugation from the measured volume of culture broth and dry cell weight was determined. Paper spot test was employed for the detection of residual glucose. Culture broth was applied to filter paper and then without developing glucose was detected with $0.1 \mathrm{M}$ anilin phthalate in water-saturated $n$-butanol. L-Glutamic acid was determined with the same method as described previously. ${ }^{14)}$

\section{Material}

Biotin was the product of Nutritional Biochemicals Corporation (N. B. C.). Avidin was also N. B.C. product and its labeled purity was 3.3 units per milligram. Tween 60 was the product of Atlas Powder Company and its analytical data were reported previously.14)
(A)

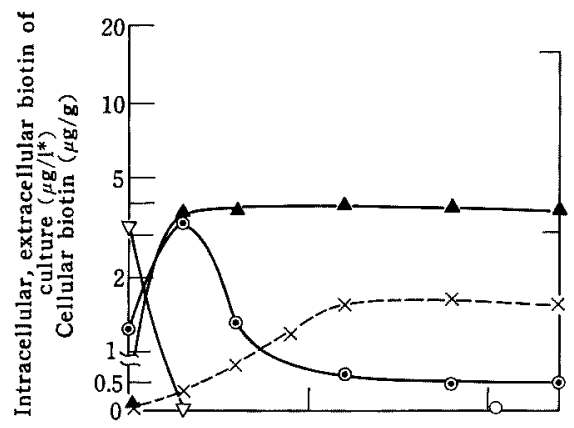

(C)

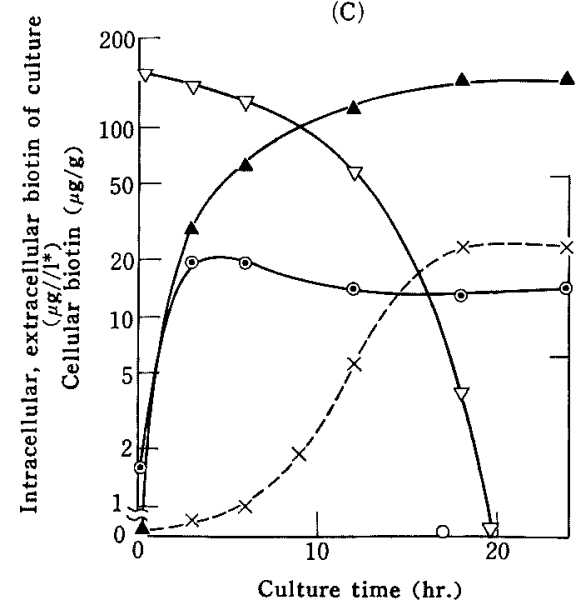

(B)

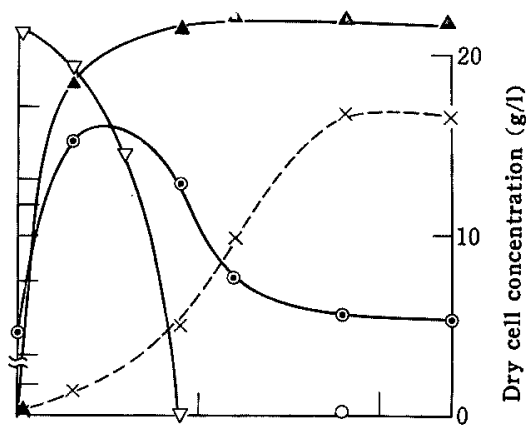

(D)

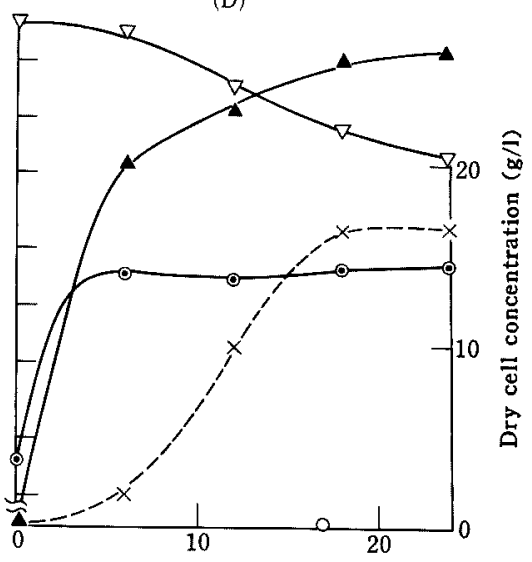

Culture time (hr.)

FIG. 1. Uptake of Biotin from Culture Medium by Growing Cells.
(A) $\mathrm{B}_{8}$ medium
$\begin{array}{ll}\text { Small amounts of cells grown on nutrient agar were inoculated. } & \text { (D) }\end{array}$
(B) $\mathbf{B}_{20}$ medium
A.: Intracellular biotin. $\triangle$ : Extracellular biotin.
* Logarithmic scale above 1.
$\times$ : Dry cell concentration. 


\section{RESULTS AND DISCUSSION}

\section{Uptake of Biotin from Culture Medium by Growing Cells}

Brevibacterium lactofermentum which was grown on the nutrient agar slant stored biotin at $1.4 \mu \mathrm{g}$ per one gram of dry cells. These cells took up biotin rapidly, when innoculated in biotin-supplemented media, as shown in Fig. 1. In the $B_{3}$ and the $B_{20}$ medium, the uptake of biotin was completed in the lag and the early exponential growth phase, and then with the advance of growth, cellular biotin which had attained to the highest levels decreased gradually in content. The final biotin levels of the cells in the $\mathrm{B}_{3}$ and the $B_{20}$ medium were respectively about 0.5 and $1.5 \mu \mathrm{g}$ per one gram of dry cells. In the $\mathrm{B}_{300}$ medium cells stopped taking up biotin in the post-exponential phase and consequently about $50 \mu \mathrm{g}$ of biotin was left over per one liter of medium. It may be considered that the cells were saturated with biotin. In this medium the bacterial growth ceased, as soon as glucose was exhausted. Evidently the amount of glucose controled the bacterial growth; for when glucose was supplied again, the cells continued to grow until glucose or other nutrients was consumed. This is the same with the $B_{300}$ and the $B_{20}$ medium. Only in $\mathbf{B}_{3}$ medium the bacterial growth was limited by biotin.

The Minimum Level of Cellular Biotin and Biotin-saturated Cells

The amount of cellular biotin is a function of biotin concentration in the culture medium as shown in Fig. 2. The cellular biotin increased as the concentration of biotin in the medium increased, if it remained within $300 \mu \mathrm{g}$ per liter. Further increase in the biotin concentration in the medium caused no increase in the amount of cellular biotin, since the cells were saturated. The maximum capacity of the cells for biotin was approxi-

* The abbreviations used are: $B_{3}, B_{20}, B_{100}$ and $B_{300}$, biotin $3,20,100$ and $300 \mu \mathrm{g} / 1$ respectively; $T_{5}$, Tween 60 $5 \mathrm{mg} / \mathrm{ml} ; \mathrm{B}_{300}-\mathrm{T}_{6}$ medium, medium composed of basal medium, $B_{800}$ and $T 5$; and $B_{800}$ cells, cells grown in $B_{900}$ medium.

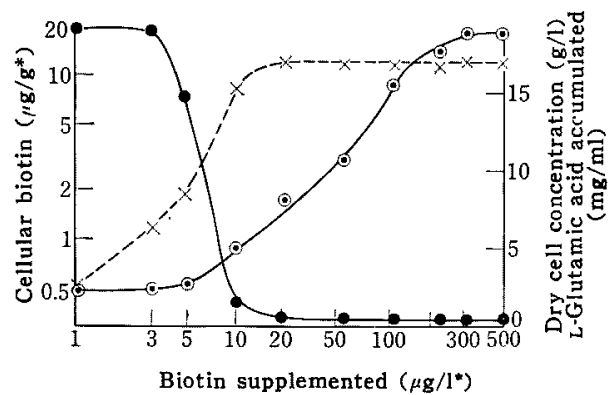

Fig. 2. Relation between the Level of Cellular Biotin and the Accumulation of L-Glutamic Acid.

Small amounts of cells grown on nutrient agar were inoculated into basal media supplemented with biotin; and cultured until glucose was exhausted in each medium, from $18 \mathrm{hr}$. (in $\mathrm{B}_{600}$ medium) to $32 \mathrm{hr}$. (in $\mathrm{B}_{1}$ medium).

O: Cellular biotin. $\times$ : Dry cell concentration.

: L-Glutamic acid accumulated.

* Logarithmic scale.

mately $20 \mu \mathrm{g}$ per gram of dry cells. The minimum level was $0.5 \mu \mathrm{g}$ per gram of dry cells. Calculation based on the molecular weight of biotin of 244.3 and the weight of a dry cell of $1.07 \times 10^{-12}$ gram indicated that $1.3 \times 10^{3}$ molecules of biotin were contained in one cell at the minimum level $\left(B_{3}\right.$ cells, $0.5 \mu \mathrm{g} / \mathrm{g}) ; 3.8 \times 10^{4}$ molecules at the saturation level $\left(\mathrm{B}_{300}\right.$ cells, $\left.20 \mu \mathrm{g} / \mathrm{g}\right)$, based on the weight of a dry cell of $7.77 \times 10^{-13}$ gram.

The biotin concentration most adequate to the accumulation of L-glutamic acid was less than $3 \mu \mathrm{g}$ per liter of medium, while $20 \mu \mathrm{g}$ or more was required for the maximum bacterial growth. And a larger amount of $300 \mu \mathrm{g}$ per liter was required in order to saturate the bacterial cells. Among these three significant levels of biotin, the two lower levels $(3 \mu \mathrm{g} / 1$ and $20 \mu \mathrm{g} / \mathrm{g}$ ) are well known respectively in the term of suboptimal, poor or deficient level and in the term of rich or sufficient level. To the third level, however, no attention has been paid as far.

Paper Chromatographic Identification of Cellular Biotin

In order to prove that biotin was released by acid hydrolysis of the $B_{3}$ and the $B_{300}$ cells, aliquots of the hydrolysates were chroma- 
tographed on paper in a solvent system composed of $n$-butanol-water-acetic acid $(4: 5: 1)$. As shown in Fig. 3, the bioautogram of cellular biotin exhibited a characteristic peak near at $R_{F} 0.85$ and was identical with that of authentic $d$-biotin. The $R_{F}$ value of biotin in the bioautograms was in good agreement with the value of 0.83 reported by Wright and Driscoll, ${ }^{22}$ and Birnbaum and Lichstein. ${ }^{23)}$

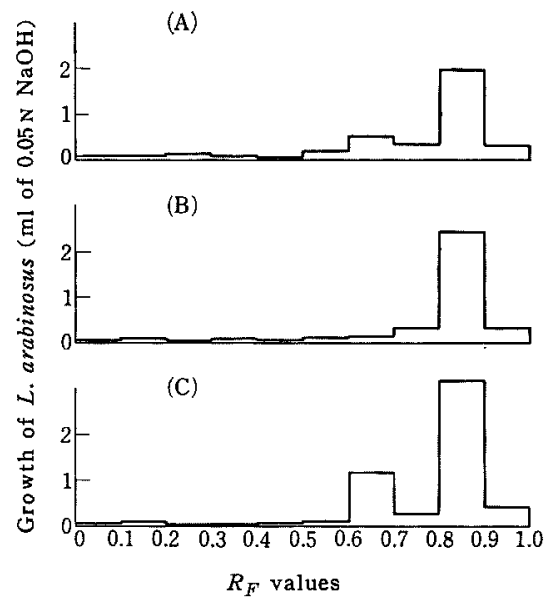

FIG. 3. Bioautogram of Hydrolyzed Cellular Biotin.

(A) $B_{3}$ cell hydrolysate.

(B) $\mathrm{B}_{800}$ cell hydrolysate.

(C) Authentic biotin.

\section{Avidin Combinability of Cellular Biotin}

Avidin, which forms a complex with biotin and renders biotin unavailable for animal and microbial growth, is used widely in biochemical investigations: for instance, the characterization of biotin analogs, ${ }^{23-25}$ ) the growth inhibition of Lactobacillus arabinosus, ${ }^{26)}$ the inhibition of enzymatic synthesis of fatty acid, $^{27)}$ and the inhibition of propionyl

22) L.D. Wright and C.A. Driscoll, J. Am. Chem. Soc,, 76. 4999 (1954).

23) J. Birnbaum and H.C. Lichstein, J. Bacteriol., 89, 1035 (1965).

24) L. D. Wright, E. L. Cresson, K. L. Liebert and H. R. Skeggs, J. Am. Chem. Soc., 74, 2004 (1952).

25) M. A. Eisenberg, J. Bacteriol., 86, 673 (1963).

26) H. P. Broquist and E. E. Snell, Arch. Biochem. Biophys., 46, 432 (1953).

27) S. J. Wakil, E. B. Titchener and D. M. Gibson, Biochim. Biophys. Acta, 29, 225 (1958). carboxylase. ${ }^{28)}$ Brev. lactofermentum was also incapable of utilizing supplemented biotin in the presence of avidin, therefore avidin was employed to demonstrate the release of biotin from $\mathrm{B}_{3}$ cells by acid hydrolysis. As shown in Table I, the growth of Brev. lactofermetum was supported with the $\mathrm{B}_{3}$ cell hydrolysate in biotin-unsupplemented medium, but it was completely inhibited by the addition of avidin. In view of the above result it was again confirmed that in fact true biotin is present in the $B_{3}$ cells, whether it is in free or bound form.

\section{Change of Cellular Biotin Content in Subsequent Growth}

When $\mathrm{B}_{300}$ cells (grown in $\mathrm{B}_{300}$ medium and saturated with biotin) were inoculated into a medium, which was not supplemented with biotin, and incubated, bacterial growth was observed in spite of the absence of exogenous biotin as shown in Fig. 4. The growth was probably supported by the cellular biotin stored previously, for the amounts of cellular biotin decreased as the dry cell concentration in the medium increased until the cellular biotin was reduced to the minimum level $(0.5 \mu \mathrm{g} / \mathrm{g})$. Fig. 4 also shows the effect of inoculum size on the accumulation of Lglutamic acid. The desirable amount of the inoculum for the maximum accumulation of L-glutamic acid was $0.2 \mathrm{~g} / \mathrm{l}$ or less (in dry weight), but more than that amount did not bring the accumulation of the acid. In the former case $(0.2 \mathrm{~g} / 1$, shown on the left in Fig. 4) the multiplication of cells caused the reduction of cellular biotin into the minimum level, and therefore the inoculated $B_{300}$ cells, which had no ability to accumulate L-glutamic acid as indicated in Fig. 2, turned into the cells possessing that ability. In the latter ( $2.1 \mathrm{~g} / \mathrm{l}$, shown on the right in Fig. 4), however, the bacterial growth stopped in the course of exponential phase because of the exhaustion of glucose, which kept the cellular biotin to a high level.

28) Y. Kaziro, E. Leone and S. Ochoa, Proc. Nat. Acad. Sci., 46, 1319 (1960). 
Accumulation of L-Glutamic Acid in the Absence of Supplemented Biotin

The above-mentioned phenomena concerning $\mathrm{B}_{300}$ cells were observed also in $\mathrm{B}_{10}, \mathrm{~B}_{20}$, $\mathbf{B}_{50}, \mathbf{B}_{100}, \mathbf{B}_{200}$ and $\mathbf{B}_{500}$ cells. When inoculated into the medium which was not supplemented with biotin, those cells which were incapable of accumulating L-glutamic acid multiplied and then accumulated the acid. This is similar to the discovery that biotin-sufficient cells of Microbacterium ammoniaphilum, cellular biotin of which was not determined, were capable

Table I. Avallability of the Biotin of Cell Hydrolysate for the Bacterial Growth AND ITS COMBINABILITY WITH AVIDIN

\begin{tabular}{|c|c|c|c|c|}
\hline $\begin{array}{c}\text { Biotin or cell hydro } \\
\text { supplemented }\end{array}$ & $\begin{array}{l}\text { lysate } \\
(\mu \mathrm{g} / \mathrm{l} \text { or } \mu \mathrm{l} / \mathrm{ml})\end{array}$ & $\begin{array}{l}\text { Avidin added } \\
(\mathrm{mg} / \mathrm{ml})\end{array}$ & $\begin{array}{l}\text { Bacterial growth } \\
(\times 26)\end{array}$ & $\begin{array}{l}\text { L-Glutamic acid } \\
\text { accumulated } \\
(\mathrm{mg} / \mathrm{ml})\end{array}$ \\
\hline None & 0 & 0 & 0.03 & 0 \\
\hline Biotin & $\begin{array}{r}1 \\
1 \\
3 \\
3 \\
10 \\
10\end{array}$ & $\begin{array}{l}0 \\
0.2 \\
0 \\
0.2 \\
0 \\
0.2\end{array}$ & $\begin{array}{l}0.28 \\
0.01 \\
0.37 \\
0.01 \\
0.75 \\
0.01\end{array}$ & $\begin{array}{c}18.6 \\
0 \\
20.1 \\
0 \\
2.4 \\
0\end{array}$ \\
\hline Hydrolysate & $\begin{array}{r}10 \\
10 \\
30 \\
30 \\
100 \\
100\end{array}$ & $\begin{array}{l}0 \\
0.2 \\
0 \\
0.2 \\
0 \\
0.2\end{array}$ & $\begin{array}{l}0.21 \\
0.01 \\
0.31 \\
0.01 \\
0.83 \\
0.03\end{array}$ & $\begin{array}{c}19.7 \\
0 \\
19.0 \\
0 \\
3.7 \\
0\end{array}$ \\
\hline
\end{tabular}

Five grams of dry $\mathrm{B}_{8}$ cells were suspended in $20 \mathrm{ml}$ of $6 \mathrm{~N} \mathrm{H}_{2} \mathrm{SO}_{4}$. After hydrolysis, the mixture was diluted with water to $25 \mathrm{ml}$. Small amounts of cells grown on nutrient agar were inoculated into basal media supplemented with authentic biotin or the cell hydrolysate, and cultured for $32 \mathrm{hr}$. in the media not added with avidin and for $18 \mathrm{hr}$. in the avidin-added media.

(A)

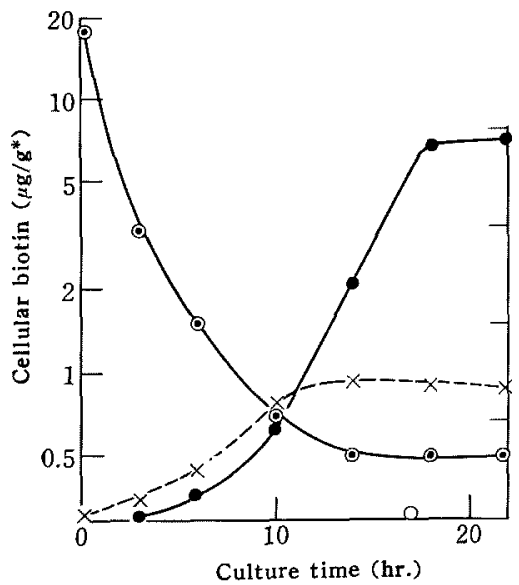

(B)

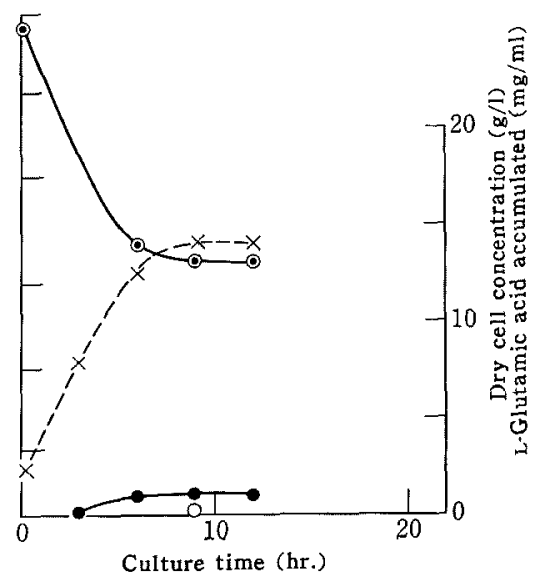

FIG. 4. Availability of Cellular Biotin for Subsequent Growth and Change of Biotin Content of Growing Cells.

(A) Initial cells, $0.2 \mathrm{~g} / 1$.

(B) Initial cells, $2.1 \mathrm{~g} / \mathrm{l}$.

Bap cells were inoculated into basal media not supplemented with biotin.

-: Cellular biotin. $x$ : Dry cell concentration.

: L-Glutamic acid accumulated. $O$ : Glucose (only final point).

* Logarithmic scale. 

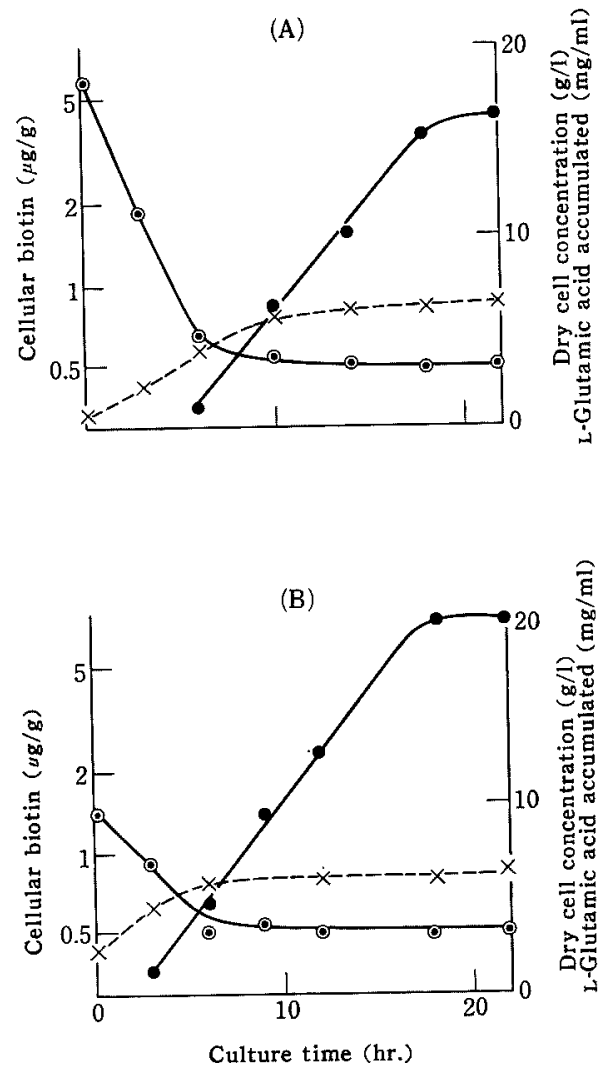

FIG. 5. Accumulation of L-Glutamic Acid in the Absence of Supplemented Biotin.

(A) Inoculum, $B_{100}$ cells.

(B) Inoculum, B20 cells.

$B_{20}$ and $B_{100}$ cells were inoculated into basal media respectively in the optimum quantities. Symbols and scales are the same as in Fig. 4.

of accumulating a large amount of L-glutamic acid in the successive culture. ${ }^{29)}$ Of the results concerning the several kinds of cells $\left(B_{10}\right.$ to $B_{500}$ cells), two examples of $B_{20}$ and $B_{100}$ cells are illustrated in Fig. 5 . These cells were inoculated respectively in the optimum quantities, so the biotin contents of the growing cells converged into a level of $0.5 \mu \mathrm{g} / \mathrm{g}$ and then the cells stopped multiplying and no further reduction of the amount of the

29) K. Miyai, R. Kodaira, I. Tsuruo, K. Goto and T. Akimoto, This Journal, 27, 243 (1963). cellular biotin was observed. At the same time cells began to accumulate L-glutamic. acid. These facts indicate that the minimum amount of the cellular biotin, $0.5 \mu \mathrm{g} / \mathrm{g}$ or $1.3 \times 10^{3}$ molecules/cell, is not only indispensable for sustaining the life of this microorganism, but essential for the accumulation of $L^{-}$ glutamic acid. It has been reported that $\mathrm{L}^{-}$ glutamic acid was produced generally by many of L-glutamic acid-producing bacteria in that particular fermentation medium which contained a suboptimum quantity of biotin. It seems reasonable to assume that in such a medium the post-exponential cells came to contain the minimum amount of biotin, just as Brevibacterium lactofermentum contained $1.3 \times 10^{3}$ molecles of biotin per cell.

\section{Effect of Tween 60 on the Change of Cellular Biotin Content}

The above-mentioned relation between the level of cellular biotin and the accumulation of L-glutamic acid was not supported with the addition of Tween 60 . The effects of the addition of Tween 60 on the L-glutamic acid fermentation have been reported in the preceding paper. ${ }^{14)}$ As for the cell multiplications and changes of cellular biotin in the subsequent cultures of $B_{3}$ and $B_{3 c 0}$ cells, the contrasts of the case of adding Tween 60 and the case of not adding it are presented in Table II. Large amounts of the cells were inoculated into these media so that the action. of cellular biotin might be distinctly exhibited. The growth of the inoculated cells in the subsequent culture attained to the maximum level, under the restriction imposed by the amount of glucose, if the cells were saturated with biotin or the medium was supplemented with sufficient biotin. In the addition of Tween 60, however, partial inhibition of growth was observed in $B_{300}$ cells and complete inhibition in $\mathbf{B}_{3}$ cells. The freshly supplemented biotin did not counteract these inhibitory effects of Tween 60 , though biotin was not prevented by Tween 60 from being taken up into cells as evidently shown in 
Table II. EFfects of TWeEn 60 on the Ghange of Cellular Brotin and the accumulation ol L-Glutamic ACid in Subsequent Culture

\begin{tabular}{|c|c|c|c|c|c|c|}
\hline \multirow{2}{*}{ Inoculum } & \multirow{2}{*}{ Medium } & \multicolumn{2}{|c|}{ Dry cells $(\mathrm{g} / \mathrm{l})$} & \multicolumn{2}{|c|}{ Cellular biotin $(\mu \mathrm{g} / \mathrm{g})$} & \multirow{2}{*}{$\begin{array}{l}\text { L-Glutamic acid } \\
\text { accumulated } \\
(\mathrm{mg} / \mathrm{ml})\end{array}$} \\
\hline & & Initial & Final & Initial & Final & \\
\hline $\mathrm{B}_{3}$ cells & $\begin{array}{l}\mathrm{B}_{0} \\
\mathrm{~B}_{0-\mathrm{T}}-\mathrm{T}_{5} \\
\mathrm{~B}_{300} \\
\mathrm{~B}_{800}-\mathrm{T}_{5}\end{array}$ & $\begin{array}{l}2.3 \\
2.0 \\
2.2 \\
2.3\end{array}$ & $\begin{array}{r}2.8 \\
2.2 \\
12.5 \\
3.0\end{array}$ & $\begin{array}{l}0.51 \\
0.51 \\
0.51 \\
0.51\end{array}$ & $\begin{array}{r}0.50 \\
0.51 \\
16.26 \\
18.17\end{array}$ & $\begin{array}{r}17.2 \\
15.8 \\
0.8 \\
15.9\end{array}$ \\
\hline $\mathbf{B}_{300}$ cells & $\begin{array}{l}\mathrm{B}_{0} \\
\mathrm{~B}_{0}-\mathrm{T}_{5} \\
\mathrm{~B}_{300} \\
\mathrm{~B}_{300}-\mathrm{T}_{5}\end{array}$ & $\begin{array}{l}2.3 \\
1.8 \\
2.1 \\
1.8\end{array}$ & $\begin{array}{r}13.0 \\
4.8 \\
13.0 \\
5.1\end{array}$ & $\begin{array}{l}18.78 \\
18.78 \\
18.78 \\
18.78\end{array}$ & $\begin{array}{r}3.28 \\
6.86 \\
16.31 \\
17.75\end{array}$ & $\begin{array}{r}1.7 \\
15.2 \\
1.5 \\
15.2\end{array}$ \\
\hline
\end{tabular}

Subsequent cultures were finished separately when glucose was exhausted in each medium.

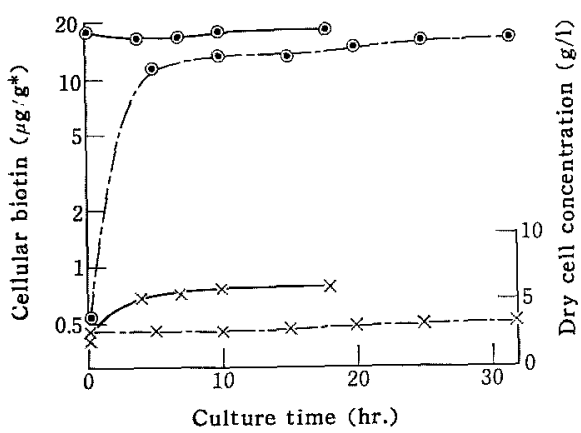

FIG. 6. Uptake of Biotin from Subsequent Culture Medium in the Presence of Tween 60.

$B_{3}$ and $B_{300}$ cells were inoculated into $B_{300}-T_{5}$ media in the initial concentration of $2 \mathrm{~g} / 1$ in dry weight.

0 : Cellular biotin. $x$ : Dry cell concentration. * Logarithmic scale.

Fig. 6. In $B_{300}-T_{5}$ medium, $B_{3}$ cells (having the minimum amount of cellular biotin) rapidly took up the supplemented biotin in the early stage of the subsequent culture and without growing turned into biotin-saturated cells. Therefore in $B_{300}$ medium cells are inevitably saturated with biotin, irrespective of the addition of Tween 60 and of the biotin level of the inoculated cells. On the other hand, in the media containing no supplemented biotin ( $\mathrm{B}_{0}$ and $\mathrm{B}_{0}-\mathrm{T}_{5}$ media of Table II) an equivalent relation was observed between the decreasing rates of cellular biotin $\left(R_{b}\right)$ and the increasing rates of dry cell concentration $\left(R_{c}\right)$ during the subsequent cultures. Calculated from the figures in Table II, their values were as follows: $\quad R_{b}-R_{c}$ of $B_{3}$ cells, 1.02:1.21 in $B_{0}$ medium and $1.00: 1.10$ in $B_{0}-T_{5}$ medium; and $\mathrm{R}_{b}-\mathrm{R}_{c}$ of $\mathrm{B}_{300}$ cells, 5.73:5.66 in $\mathrm{B}_{0}$ medium and $2.74: 2.67$ in $B_{0}-T_{5}$ medium. From the results that large amounts of $\mathrm{L}$-glutamic acid were accumulated in $B_{300}-T_{5}$ medium as well as in $B_{0}-T_{5}$ medium, it may be considered that Tween 60 was completely repressive to the action of biotin which was taken up freshly into the cells in the subsequent growth. It is more interesting that the diminution of the amount of cells in the final stage was necessary to the maximum yield of L-glutamic acid in the subsequent culture.

Partial Inhibitory Effects of Tween 60 and Saturated Fatty Acid on Subsequent Growth

Tween 60 entirely hindered the action of biotin freshly taken up in the course of subsequent culture, but it had partial effect on cellular biotin which had been stored beforehand in the cells. As shown in Fig. 7, the growth-repressing effect of Tween 60 is evidently based on that of saturated fatty acid. This is supported by the fact that the fatty acid composition of the ester is as follows: myristic acid (3.7\%), palmitic acid (38.3\%), margaric acid $(5.4 \%)$ and stearic acid $(50.0 \%) .{ }^{14)}$ It is more interesting that complete inhibition was not observed with increasing amounts of the fatty acids. The results thus obtained offer the suggestion of there being a portion of cellular biotin which is not subjected to the effect of the fatty acids, or it may be other growth promoting substance than biotin. 


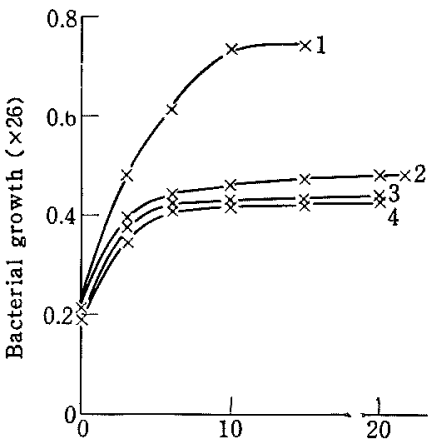

Culture time (hr.)

FIG. 7. Partial Inhibitory Effects of Fatty Acid on Subsequent Growth of Biotin-saturated Cells.

Bsoo cells were inoculated into basal media added with saturated fatty acids or Tween 60 .

Curve 1: None.

2: Tween $605 \mathrm{mg} / \mathrm{ml}$.

3: Stearic acid $1 \mathrm{mg} / \mathrm{ml}$.

4: Myristic acid $1 \mathrm{mg} / \mathrm{ml}$.

\section{SUMMARY}

1. Brev. lactofermentum rapidly removed biotin from culture medium. The amounts taken up exceeded the quantities required for maximal growth. Two significant levels of cellular biotin were observed in this microorganism. They are a minimum level most adequat to the accumulation of L-glutamic acid (approximately $0.5 \mu \mathrm{g} / \mathrm{g}$ ), and a saturation level (approximately $20 \mu \mathrm{g} / \mathrm{g}$ ).

2. Biotin stored in cells was metabolically available, if the cells were subsequently placed in a medium lacking in biotin. In the subsequent culture, the biotin level of cells was gradually reduced to the minimum level $(0.5 \mu \mathrm{g} / \mathrm{g})$, as the cells multiplied, and then the accumulation of L-glutamic acid began.

3. The addition of Tween 60 in the subsequent culture impaired the relation between the level of cellular biotin and the accumulation of L-glutamic acid. Since Tween 60 was incapable of preventing biotin from being taken up, it hindered the action of the absorbed biotin. Therefore, even biotin-saturated cells accumulated L-glutamic acid in the presence of Tween 60.

4. Saturated fatty acids with fourteen to eighteen carbons as well as Tween 60 had partial inhibitory effect on the subsequent growth of the biotin-saturated cells.

5. The bioautograms of the acid hydrolysates of the cells exhibited a characteristic peak near to $R_{F} 0.85$ and were identical with that of authentic $d$-biotin, using $L$. arabinosus as an assay organism. In addition, the growth of Brev. lactofermentum was supported by the hydrolysate of the cells with minimum biotin, and the combinability of avidin with the biotin in the hydrolysate was observed in the culture of this microorganism. From these observations, the existence of biotin was evidently demonstrated in the cells.

Acknowledgement. The authors are grateful to Dr. T. Tsunoda for his helpful discussions and suggestions, and they are also much indebted to Mr. T. Suzuki for the microbiological assay of biotin. 